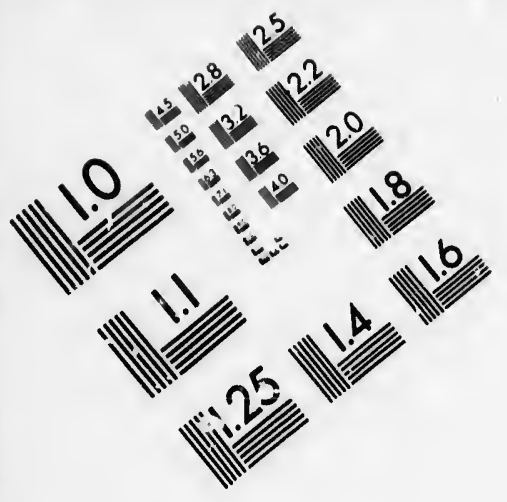

IMAGE EVALUATION

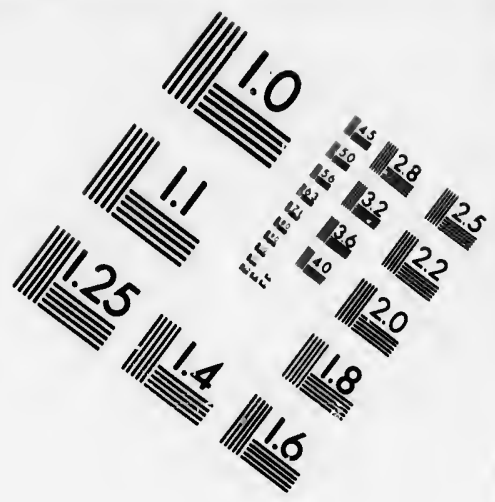

TEST TARGET (MT-3)
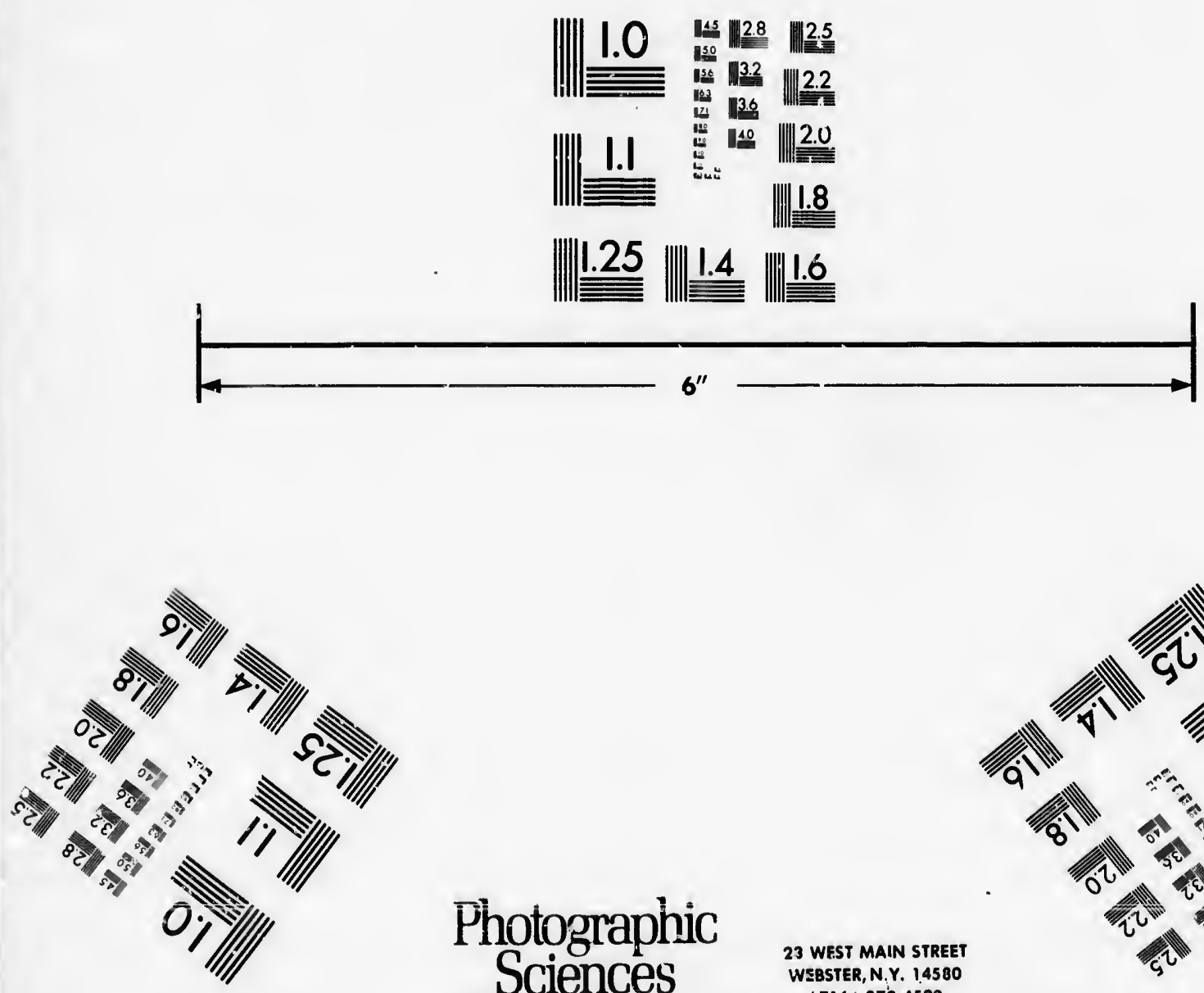

Photographic Sciences Corporation

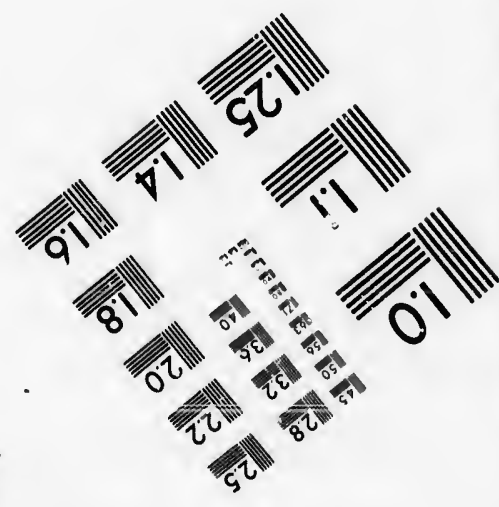




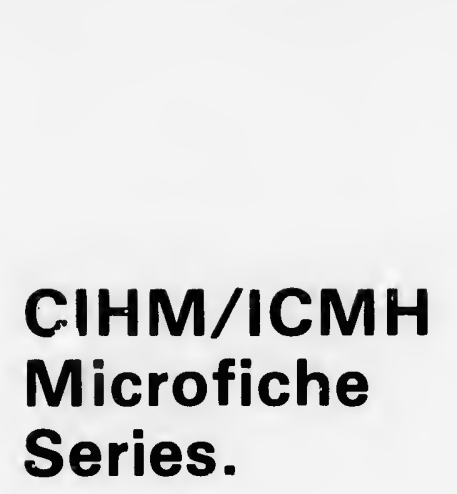

C.IHM/ICMH Collection de microfiches.

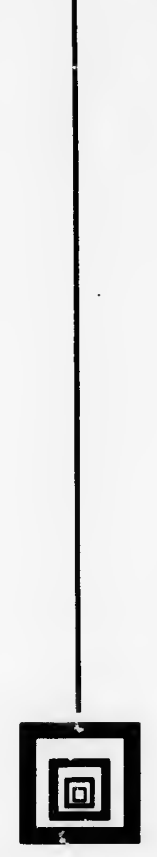

Canadian Institute for Historical Microreproductions / Institut canadien de microreproductions historiques
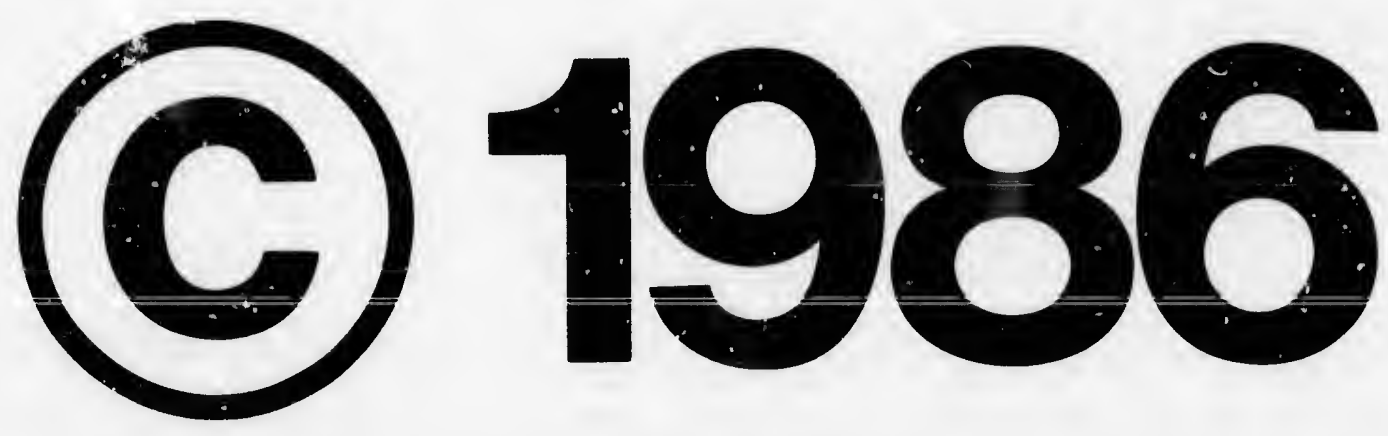
The Insticute has attempted to obtain the best original copy availeble for filming. Feetures of this copy which may be bibliographisally unique. which may alter any of the images in the reproduction, or which may significantly change the usual method of filming, are checked below.

Colourad covers/

Couverture de couleur

Covers damaged/

Couverture endommagée

Covers restored and/or laminated/

Couverture restaurde et/ou pelliculée

Cover title missing/

Le titre de couverture manque

Coloured maps/

Cartes géographiques en couleur

Coloured ink (i.e, other than blue or black)/

Encre de couleur (i.e. autre que bleue ou noire)

Coloured plates and/or illustrations/

Planches et/ou illustrations en couleur

Sound with other material/

Relie avec d'autres documents

Tight binding may cause shadows or distortion along interior margin/

La reliure serrée peut causer de l'ombre ou de la distorsion le long de la marge intérieure

Blank leaves added during restoration may appear within the text. Whenever possible, these have been omitted from filming/

II se peut que certeines pages blanches ajoutées lors d'une restauration apparaissent dans le texte. mais, lorsque cela était possible, ces pages n'ont pas eté filmóes.

Additional comments:/

Commentaires supplémentaires:
L'Institut a microfilme le meilleur exemplaire qu'il lui a été possible de se procurer. Les détails de cet exemplaire qui sont peut.être uniques du point de vue bibliographique, qui peuvent modifier une image reproduite, ou qui peuvent exiger une modification dans la méthode normale de filmage sont indiqués ci-dessous.

\section{Coloured pages/}

Pages de couleur

Pages damaged/

Pages endommagées

Pages restored and/or laminated/

Pages restaurées et/ou pelliculées

Pages discoloured, stained or foxed/

Pages décolorées, tachetées ou piquées

Pages detached/

Pages dérachées

\section{Showthrough/}

Transparence

Quality of print varies/

Qualité inégale de l'impression

Includes supplementary material/

Comprend du ma:ériel supplèmentaire

Only edition available/

Seule edition disponible

Pages wholly or partially obscured by errata slips. tissues, etc., have been refilmed to ensure the best possib!e image/

Les pages totalement ou partiellement obscurcies par un feuillet d'errata, une pelure. etc., ont été filmées a nouveau de façon à obtenir la meilleure image possible.

This icem is filmed at the reduction ratio checked below/ Ce document est filmé au taux de réduction indiqué ci-dessous.

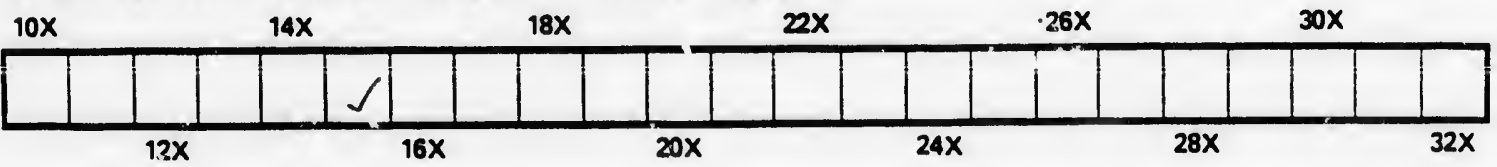


The copy filmed here has been reproduced thanks to the generosity of:

D. B. Weldon Library

University of Western Ontario

(Regional History Room)

The images appearing here are the best quaiity possibie considering the condition and leglbility of the originei copy and in keeping with the fllming contract specifications.

Originel coples in printed peper covers ere filmed beginning with the front cover and ending on tha iast paga with a printed or iliustrated impression, or the back cover when approprlate. All other originai copias are fiimed beginning on the first page with a printed or iliustrated impression, and ending on the last page with a printed or iilustrated impression.

The last recorded frame on eech microfiche shail contain the symbol $\rightarrow$ (ineaning "CONTINUED"), or the symbol $\nabla$ (meening "END"). whichever applies.

Maps, piates, charts, etc., mey be fllmed at different reductlon ratios. Those too large to be antireiy inciuded in one exposure are filmed beginning in the upper left hend corner, ieft to right and top to bottom, as many frames as required. The foilowing diagrems iilustrate the mothod:
L'exempiaire fllmé fut reproduit grâce à la gónórosité de:

\author{
D. B. Weldon Library \\ University of Western Ontario \\ (Regional History Room)
}

Les Images sulvantes ont étb reproduites avec la pius grand soln, compte tanu de la condition at de le netteté de i'exempiaire fiimé, at an conformite avec ies conditions du contrat de flimage.

Les exempiaires originaux dont ia couverture an papier est imprimbe sont fiimbs on commençant par lo premier plat ot en tarminant soit par la dernldre page qui comporte una amprainta d'impression ou d'iliustration, soit par la second plat, selon le cas. Tous les autres examplaires originaux sont filmós an commencant par la premidre page qui comporte une amprainta d'impression ou d'illustration at en tarminant par la dernidre page qui comporta une telia empreinte.

Un des symboles suivants apparaitra sur la dernière image de chaque microficha, seion le cas: ie symbole - signifie "A SUIVRE", ie symbole $\nabla$ signifie "FiN".

Les cartes, pianches, tabieaux, atc.. peuvent êtra fiim des a des taux de róduction différants. Lorsque le document est trop grand pour atre reproduit en un seui cliché, if est fiimé à partir de l'angle supérieur gauche, da gauche à droite, ot de heut an bas, en pranant la nombra d'images nécassaire. Les diagrammes suivants iiiustrent ia méthcde.
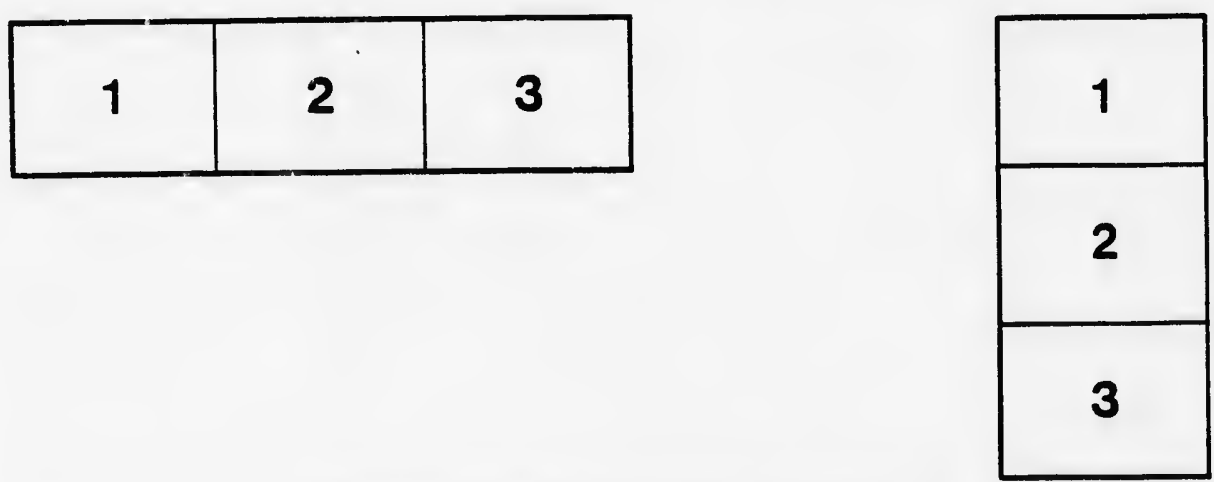

\begin{tabular}{|l|l|l|}
\hline 1 & 2 & 3 \\
\hline 4 & 5 & 6 \\
\hline
\end{tabular}




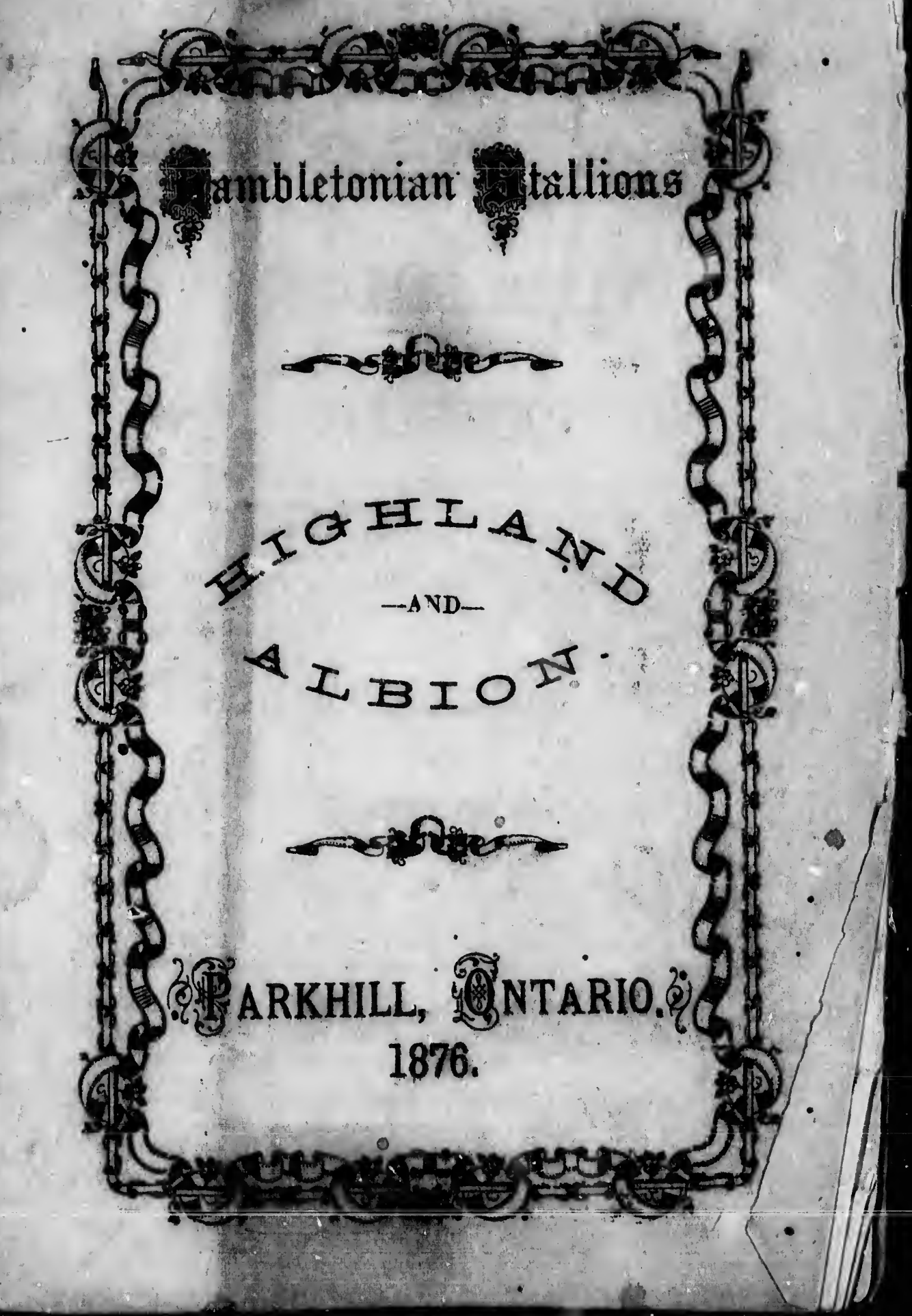




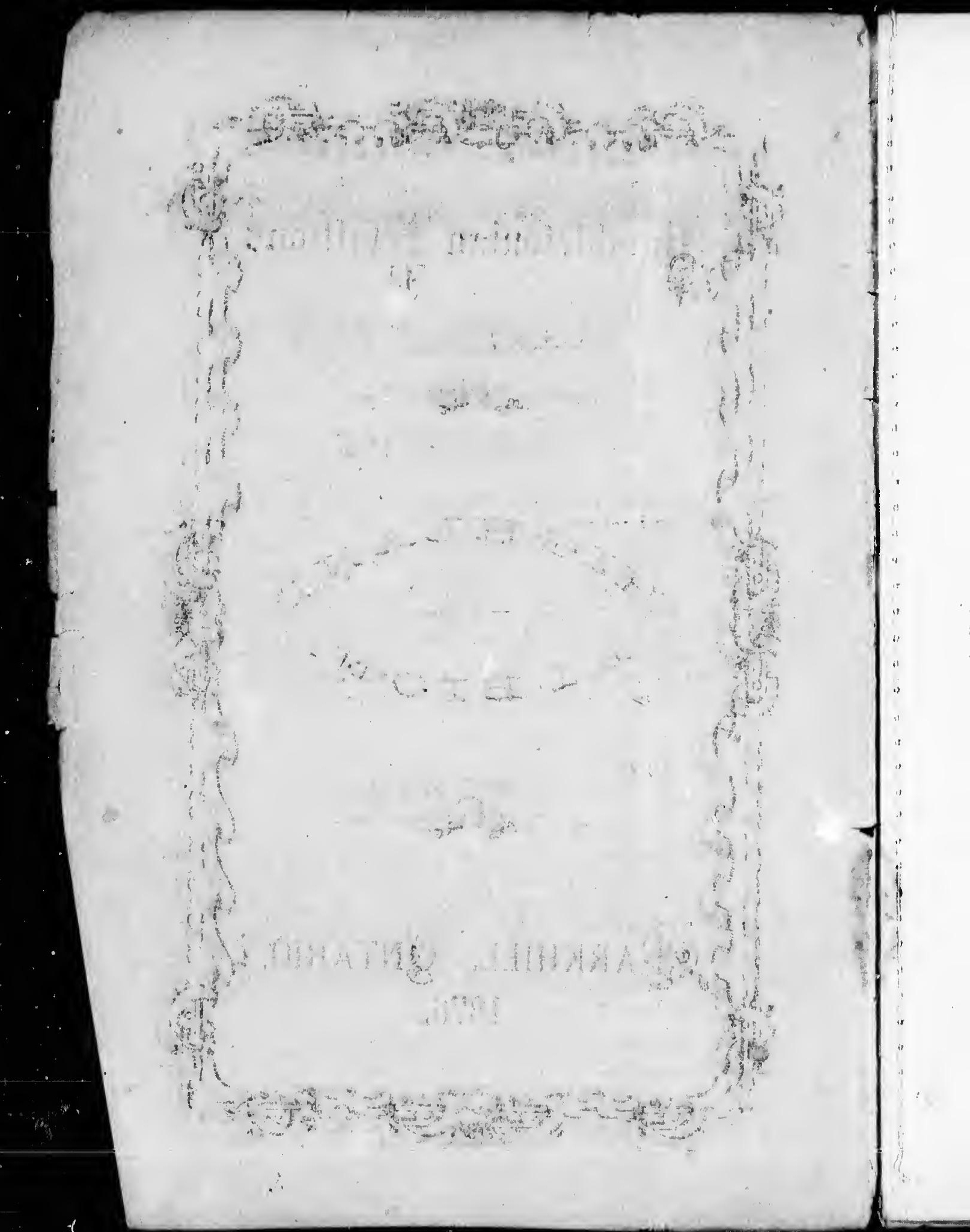


TEF

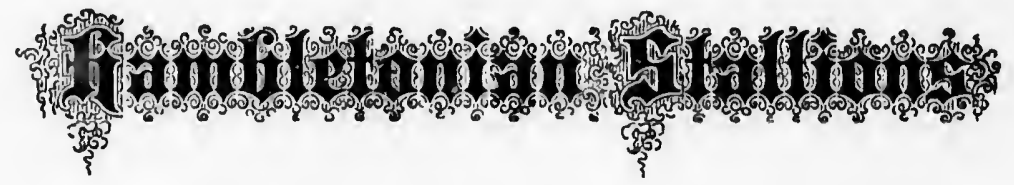

"HIGHLAND” - AND-

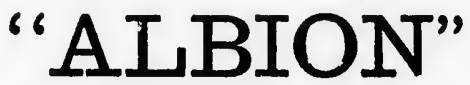

Will be kept for the Service of Mares this Season of 1876, ( mencing April 1st and Ending August 1st, at the Royal Hotel Stables, Parkhill, on the main line of the Grand Trunk Railway, except the following days of each month of May, June and July, viz.:-From the 9 th to the 12 th and from the 28th to 31st of Mar, and from the 6 th to the 9 th and from the 27 th to 30 th of June, and from the 4 th to the 7 th and from the 25th to $28 \mathrm{th}$ of $\mathrm{J}: 1 \mathrm{y}$, inclusive, at which dates they will be located at the Western Hotel Stables in the Crty of London, and continue this Route during tho above dater, Health and Weather permitting.

\section{IIERIMS:}

HIGHLAND- $\$ 30$ by the season, payable by note at 3 months from date of service, with the piivilege in the event of the mare not proving with foal of retuning her free of charge in 1877, provided she is returned punctually for service during this season.

ALRION- $\$ 20$ by the serson, parable on the same conditions as "Highland," and will be found at the same time and places, health and weather permitting.

Mares will be carefully stabled or pastured, and fed on grain as the owners desire, at the most reasnnable rates. The utmost care anc attention will be taken, but all escapes and accidents will be at owner's risk. 


\section{PEDIGIREF \\ $-\mathrm{OF}-$ \\ "HIGHLAND."}

Was bred by Alfred Post, Esq., of the City of Newburg, Orange County, State of New York, foaied on the farm of Mr. Chas. W. Post, at Hamptonburgh, in said County, on the 15th day of July, 1867. Sired by the old Hero of Chester, Rysdyk's Hambletonian. 1st dam "Emily", by Smith's Hambletonian ; lie by Vermont Hambletonian ; he by Harris' Hambletonian ; he by Bishop's. Hambletonian. by Imported Messenger. 2nd dam by Andrus' Hambletonian ; he by Judson's Hambletonian; he by Bishop's Hambletonian by Imported Messenger. 3rit dam by Abdallah; he by Membrinn by Imported Messenger and sire of Rysdyk's Hambletonian.

E'mily, Highrand's dam, was bred by M. N. Vail, Esq., of Delnware County, State of New York, and was purchased by $\mathrm{Mr}$. Post, at a high price, who owned her for upwards of five years previous to having her bred to Hambletonian; has since been sold to a breeder of New York, and is now being stinted to one of Charles Backmou's fine Stallions. She is a very bandsnme, fine-bred mare, possessed of great speed, power and endurance, and of a kind and gentle disposition.

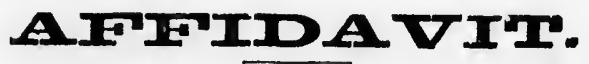

Orar ge County, State of New York.

I, Alfred Post, of the City of Newburgh, in the said County of Orange, anil State of New York, being duly sworn, do depose and say, that I am the owner of the Brown Stallion Horse called Highland. 'Thj alove statement and pedigree as to the sire Doponent knows to be true of his own personal know. ledge, and the statements as to the clarr are true to the best knowledge, i.aformation and belief.

Signed,

Aufred Post.

Sworn to before me this).

1st day of June, 1875. ;

M. C. BELKNAP,

Notary Puiblic in and for the Cointy of Orauge and State of New York. 
In addition to the abcive affidavit of Mr. Post as to the breed. ing of Hrghus which appeared in the Tunf, FJEzD AND Farm of 30th July, 1875.

"Subscriber, Londin, Ont.-Kindly auswer the following, and oblige many. Inclosed please find pedigree of stallion which has been brought here by J. H. Dulmase, who represents that he got this horse through the agency of Messrs. Bruce \& Co., New York. Ho also brought with the horse the sworn affiduvit from the owner as to the personal knowledge of his breeding, \&c. No person has reason to doubt Dulmage's statements ; only there are grave doubts, as, from the set forth peidigree, it seems strange that he should come to Canada to do service at such very low figures. My only object is to arrive at , he truth. for should his breeding and representations by Dulmage prove true this horse will prove a very great acquisition to this part of Canada. 1 Did Dulmage get horse through the agency of Messrs. Bruve \& Co.? 2. Is Alfred Post a responsible person? 3. What value in cash was set on this stallion? 4. Is the inclosed statements of Dulmage true? 5. Would this horse throw trotters from good dams? 6 . Is there $n$ better horse to breed to in Canala? This is a very fine and handsome looking stallion. and has a good share of speed, and many would $k$ e glad to use him providing his redigres is incontestible. Axs. wer. - The horse described as taken to Canada by Mr. J. H. Dulmage was obtained in this city through the a gency of Messrs. Bruce $\&$ (io. His pedigree is correct as represented in the affidavit of the former owier. Mr. Alfred Post is president of the Newburgh Bank, and is a gentleman of unquestioned veracity. "The value in cash" set on the animal is a matter solely between the purchas. er and seller. There is no rerson to donbt that the horse will get "trotters from good dams;" his fine breeding will warrant the opinion. There are doubtless other good trotting stallions in Canada, but it is not reasonable to expect us to make any invidi-
ous comparisons."

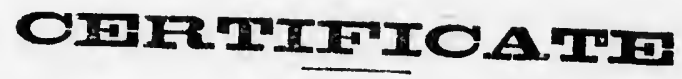

This is ro Cen'riny that on the 25th day of July, 1866, Chas. W. and Alfred Post, brothers, Foth of (Mrange County, and State of New York, had a mare served by Rysdyk's Hambletonian, and that sard mare the following summer produced a colt foal, and that all charges thereon have been paid. GEORGE F'. ANDREWS,

Chester, Jall. 10th, 1876. Att'y for ELviRA RYSDYK, Owner of HaMBIETONIAN. 
This identical colt mentioned in the annexed Certificate of Geo. W. Andrews, attorney for Elvira Rysdyk, dated Jan. 10, 1876, montinued in the care of Chas. W. Post, of Hamptonburgh, Orange County, N. Y., up to the time of his death, in the fall of the year 1871, at which time Hianlasd was removed to the stables of A. N. Taylnr, in Munroe, and from thence to New . burgh, in the care of James Hasbrouch.

\section{ALFRED POST.}

County of Orange, State of New York.

Sworn to and subscribed before me this 12th day of Jan., 1876.
M. C. BELKNAP, Notary Public in and for Orunge Co.

\section{RYSDYK'S HAMBLETONIAN}

Sired by Abdallah. First dam, Chas. Kent's More, by Imported ed Bellfounder. Second dam, Ono-Eye, by Bishop's Hambletonian. Third dam Silver Tail, by Imported Messenger.

\section{ABDALLAH}

By Membrino, son of Imported Messenger. Dam, Amazonia, by a son of Imported Messenger.

\section{HARRIS' HAMBLETONIAN}

By Bishop's Hambletonian. Dam, the Munsow Mare, by Import eul Messenger.

\section{BISHOP'S HAMBLETONIAN}

By Imported Messenger. First dam, Pheasant, by Imported Shark. Second drm, by Imported Medley.

\section{SMITH'S HAMBLETONIAN}

By Vermont Hambletonian. Dam unknown.

\section{VIRMONT HAMBLETONIAN}

By Harris' Hambletonian. Dam bv Comet, a son of Bishop's Hambletonian.

\section{ANDRUS' HAMBLETONIAN}

By Judson's Hambletonian. Dam unknown.

$$
\text { JUDSON'S HAMBLETONIAN }
$$

Bỵ Bichnp's Hambletonian. Dam by Wells' Magnum Bovum. 
It will be seen from the pedigreo of Hamuan (which, by the way, is incontestible) that he is a closer inbred HambletonionMessenger than any living stallion in America. And it is claimed, on necount of his being so strongly inbred, thint he possesses to a large degree the transinitting power to stamp his progeny in likeness and form after his noted sire, and to transmit the trotting instinct also in a marked degree. It would bo ncedless for me to say anything in favor of this wonderful breed of horses as it is admitted by every intelligent remler that as a family of horses they have no equals. It can be seen from the records that liysdyk's Hambletonian is the sire and grandsire of more fast and stont trotters than all other breeds combined; the extrnordinary prices asked for his services warrants this opinion, beng limited to 30 mares yearly, at $\$ 500$ each. His sons and grandsons are also lield in high estimation. Many of them are held at from $\$ 100$ to $\$ 300$ each servire. In conclusion, allow me to say to the breed. ers of Cauada that I have brought this superior-bred stallion, for Stock pmiposes, to this comntry at considerable expense in order to improve the form, and transmit the trotting instinct to our Canadian roadsters, and as HighlaNo and his half-brother, at Prescott, are the oxisy sons of that noble horse now standing in this Province his services ought, and no doult will be accepted by many.

The following extract from Wilkes' Spinit or' The 'linses of Nov. 25th, 1875, clearly slows the estimation in which this noble breed of horses is heli by the Filitor of this leading Journal.

"TVe presume thrt none will venture to dispute the fact that, by virtue of the record, Brsalyl's Hambletonian unquestionably de. serves to rank at the head of trotting sires. He was bred by Jonas Seely, of Chester, Orange County, N. Y.; foaled May 15, 1849; got by Abdallah, son of Membrino, by imp. Messenger. Abdallah, his sire, was out of Amazonia, who was first claimed as by Messenyer, thes: by a son of Messonger ; but it is now generaliy conceded that ier blood is entirely unkmown. She maY Have been got by $n$ :on of Messenger, hit the evidence unon which the story rests is fon fimsy to caryy with it any weight. But, notwithstanding her unknown lincare, she grave to the world, in her son Abdallah, one of the greatest horses that ever brot American sovi-m "rough tolook at, wht king anong stallions." Hambletonion's dam was by imp. Bellfomder ; second dam by Hambletonian (a son of Messenger); third dom by Mres nger ; which gives him one direct cross of the highly-prizeil Messenger blool on the side of his sire, and a double cosi on the side of his dam. The dam, with the colt (subseqnent1. Rysirk's Hambletonian) by her suie, was sold by Mr. Seely to IIr. W. M. Rysily, of Clester, for \$125. Mr. Rysciyk was at that fime in very limited cirvimstances; but he was an astute horgenum, anr, hy his shrewrhess, managed to direct public attention 
to the colt at a very early age. When he was two years old four mares were bred to him, from which resulted three fonls, one of which afterwards became famous under the name of Alexander's Abdallah, the sire of Goldsmith Maid. It is worthy of romark, in this connection, that this greatest of all trotting mares should have been begotten by a three-year-old, and he, in turn, by a two-year. old colt. At three years old he was taken to Long Island, aud underwent a few months' training as a trotter, but the promise which he showed upon the track was not deemed sufficient to warrant a continuation of the training, although he showed a trial of a mile in 2.48, and he was retired permanently to the breeding sturl. Up to tha year 1854 , his service-fee was $\$ 25$ to insure a fonl, but it was then advanced to $\$ 35$, at which it was kept to the year 1863 , when it was advanced to $\$ 75$, and, owing to the fame which his began to acquire about this time, his services were in great demand at the increased price. In 1864 the fee was placed at $\$ 100$, and in the year following to $\$ 300$, during which two sensons he was permitted to serve the unprecedented number of four hundred and ten mares, from which there were produced two hundred and seventy. six foals. His fee was then fixed at $\$ 500$, at which it remains up to this time. During the entire season of 1868 he was retired fron the stud, so that there were no sons or daughters foaled to him in 1869. Since that time he has been limited, each season, to a very small number of mares, and, although now twenty-six ynars old, is active, strong and vigorons. He has sired more fonls, perhaps. than any other stallion of any age, the number reaching near 1,325, which is conclusive evidence of his wonderful constitutional vigor. In a pecunicry sense he has also been a wonderfui success, the fees reccived for his services agrregating $\$ 100,000$. It will be a matter of surprise to many to learn that no less than fifty-eight descendants of this famous old sire have made rublic records of 2.30 or better, twenty-one of which are in the first generation. Of the remaining thirty-seven there i re thirty two grand-sons and daughter's, and five that are one generation further removed from their distinguished progenitor. Of those in the second generation twenty-nine are descended in the male line, two in the female line and one by both branches. Of the sixty-one horses that have made records of $2.2: 3$ or better in harness, twenty-one are his descenrlants, and of the tein that have dropped in to the 2.18 class, he clanms just one-half $-\Omega$ showing from the records that clearly entitles him to

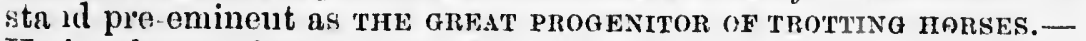
$\mathrm{He}$ is a hor'se of great substance, but, at the same time, withont a purticle of grossness. His bone, though heavy, is of wost excellent form and apparent finenes: of texture. His mane was originally lisht, the hairs porfely straight, but not a vestige of it remains. His tail was conce very heavy, but it is also growing thin with age. In color he is a rich inahogany bas, with a small star, and two 
white ankles behind, but below them the coronets are dotted with black spots, and the hoofs are mainly dark. His head is large and bony, inclining to what is known as the "Roman-nose" type; jowl deep ; oyes large and promiv sit ; ear large; neck rather short, and heavy at the throaclutch, but thin and clean; shoulders very deep, oblique and stiong; withers low and broad; back short; coupling excellent; croup high, and enormous length from point of hip to hock; broad, flat, clean legs, with tendons well detached from the bone; hock well bent rather than etruight; pasterns long and elastic; and hoofs splendid."

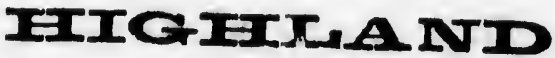

Is in color a rich Brown, with tamed muzzle, and flanks free from any white innrks; stands 15 hands 1 inch without shoes; weighs 1120 lbs.; is of immense power and substance; has a beantiful, irtelligent hoad ; large, full eyes; good leugth of neck, of fine shape, and well cut out at the throttle, set on strong oblique shoulders; has a long, full, flowing mane and tail ; a handsomely moulded middlepiece, with fu,l length of ribs, giving ample room for the vital organs. His loins are broad and arched at the coupling, a grand essential for a good repeater, while his broad hips and woll-developel quarters tell plainly of a wealth of driving power; his limbs being as flat and cleanly chiseled as $n$ thorough-bred and sound and alike in texture. His action is very fine, having a bold. reso. lute, commanding gait, which is level and even in all his movements; has a fast, industrious walk, a grand requisite in a road horse : is of a kind and gentle disposition. His work for the devolopment of sperd has been vesy limited, not having scarcely one year's work. At the death of Chas. Post he was turned out in a yard, where he remained until he came into my charge, in the fall, when rising four y cars old. He showed wonderful speed for his age and was thought well of by his handler. Since his arrival here his work has been very light; at no time severe or urgent, I have found him an improving horse and willing to do his best under any and all circumstances : has showed several half-mile trials and at each time dropped a little from 1.20 to 1.16 , to a ninety-five poun ls sulkv. I am confident when in proper condition can trot a full mile within the thirties. 


\section{"ALBION"}

Was foaled May 24th, 1871. Bred by Moss Olmsted, Esq., of Monnt Albion, Ontario. Sired by Mr. James' fine stallion "Highland Boy ;" he by Hamlet ; he by Volunteer; he by Rysdyk's Hambletonian, ont of Black Maria by Membrino Chief.

The pedigree of Ars.on's dam not yet triced but will be placed before the public as soon as all the true facts can be olntained. This is a very fine mare and is considered one of the best broo mares in this part of Ontario. She was recently purchased, at a high price, for stock purposes, by Messrs. Geary \& Hodgins, and can be seen at any time on Mr. Geary's Stock farm, three miles north of London.

Arsion is in color a brantiful Golden rhestmut, with three white feot; stands full 16 hands high, and weighs, in fleshy condition, 1209 lhs.; has invarielly been pronounced by judges of fine lorses the most periect formed stillion in this country, and must be seen to be admired. His action is most perfect and, althongin has never had more work than tc steady him in harness, I am prepared to show breedurs speed enough to satisfy thern to their fullest desire, and I will be most happy to exhibit either of these stallions to breeders of this comtry by giving me notice to that effect.

For any further infermation required letters addressed to $j$. H. Dulmage, Parkhill, will receire prompt attention.

Parkhill, April 1st. 1876.

$$
\text { T. H. DLLMAGE. }
$$

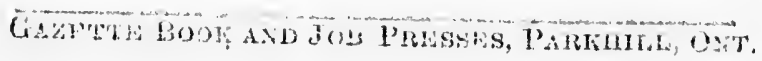


Esq., of stallion by Raysof.

es placed

mined.-

it brood

ins, and

miles

h three

thy con-

of fine

1 mist

lthongin

am pres-

ir full-

of these

to that

I to J.

SE. 
